\title{
Baseline study of the distribution of marine debris on soft-bottom habitats associated with trawling grounds in the northern Mediterranean
}

\author{
PILAR SÁNCHEZ, MERCEDES MASÓ, RAQUEL SÁEZ, SILVIA DE JUAN, \\ ALBA MUNTADAS and MONTSERRAT DEMESTRE \\ Institut de Ciències del Mar, CSIC, Passeig Marítim de la Barceloneta 37-49, 08003, Barcelona, Spain. \\ E-mail: pilar@icm.csic.es
}

SUMMARY: The present study aims to analyse the local and regional variability in the density and typology of marine debris on fishing grounds on the northern Mediterranean continental shelf, and to test relationships between marine litter and trawl fishing activity. Moreover, the colonization of plastics was examined in order to study the importance of plastics as a source of impact on marine communities and their further environmental implications. This study surveyed 11 sites, associated with trawling grounds and subjected to different levels of fishing intensity, located in four areas of the Mediterranean: one in Italy, the Central Tyrrhenian coast, one in Greece, the eastern Ionian coast, and two in Spain, the Murcian and Catalan coasts. Samples were collected during an oceanographic cruise undertaken from the 21 May to the 24 June 2009. Results showed geographical variation in the density of marine debris which ranged from 0 to 405 pieces per hectare in the surveyed areas, plastics being the dominant components. Variability within sites was higher than between areas, indicating small-scale patchiness in the distribution of the debris over the seafloor. Though the study areas were within trawling grounds, the density of debris was not significantly correlated with fishing effort. More than $30 \%$ of plastics were between 10 and $20 \mathrm{~cm}$ width/ length, and more than $40 \%$ of the plastics were colonized by a biofilm of microorganisms, suggesting indirect effects on benthic communities.

Keywords: marine debris, seabed plastic accumulation, colonized benthic plastics, northern Mediterranean Sea.

RESUMEN: ESTUDIO DE REFERENCIA SOBRE LA DISTRIBUCIÓN DE BASURA MARINA EN FONDOS BLANDOS ASOCIADOS A CALADEROS DE PESCA DE ARRASTRE EN El MEDITERRÁNEo NORTE. - Este estudio tiene como objetivo analizar la variabilidad local y regional de la basura marina en caladeros de pescas de la plataforma continental mediterránea septentrional y estudiar la relación entre ésta y la actividad pesquera. En este estudio se examinaron once estaciones de muestreo asociadas a caladeros de pesca, sujetas a distintos niveles de esfuerzo y situadas en 4 áreas en el Mediterráneo: una en Italia, en la costa central del Tirreno (TC), otra en Grecia, en la costa jónica occidental (IC) y otras dos en España, en las costas murciana y catalana (MC y CC). Las muestras se obtuvieron durante una campaña oceanográfica llevada a cabo entre el 21 de mayo y el 24 de junio de 2009. Los resultados mostraron una variación geográfica en la densidad de basura marina comprendida entre 0 y 405 piezas por hectárea en las áreas muestreadas, siendo los plásticos el componente principal. La variabilidad entre estaciones resultó más alta que la variabilidad entre áreas, lo que indica una heterogeneidad a pequeña escala en la distribución de la basura sobre el fondo. Aunque las áreas de estudio estaban situadas en caladeros pesqueros, la densidad de basura no mostró una correlación significativa con el esfuerzo de pesca. Más del $40 \%$ de los plásticos se encontraron colonizados por un biofilm de microorganismos y más del $40 \%$ presentaba dimensiones de entre 10 y $20 \mathrm{~cm}$ ancho/largo. Se examinó la colonización de los plásticos con el fin de estudiar su importancia como fuente de impacto en las comunidades marinas y sus posibles implicaciones ambientales.

Palabras clave: basura marina, acumulación plásticos fondo marino, colonización plásticos bentónicos, mar Mediterráneo Norte. 


\section{INTRODUCTION}

The noxious effect of plastic pollution on marine populations has been known since the 1960s. The list of their potential harms has increased considerably and plastic pollution is now considered a real threat to marine populations and biodiversity (see reviews Derraik 2002, Gregory 2009, Galgani et al. 2010). In addition to the negative effects on marine mammals, turtles and seabirds, marine plastic contamination can also indirectly alter the ecosystem structure, e.g. through the introduction of alien or invasive species by floating plastics (Barnes 2002, Aliani and Molcard 2003, Masó et al. 2003), and can consequently modify the ecosystem functioning (Derraik 2002). Moreover, the accumulation of floating microplastics in convergence zones and its negative impact on marine populations through their incorporation into the food web have recently called the attention of the scientific community (Boerger et al. 2010, Aloy et al. 2011, Graham 2011). However, these indirect consequences are still poorly known.

Although the majority of plastics have positive buoyancy, it is believed that most plastics are currently accumulated on the oceans' seabed and will persist there for hundreds or even thousands of years depending on the properties of the polymer (Stefatos et al. 1999, Barnes et al. 2009, Galgani et al. 2010). A recent review (Barnes et al. 2009) illustrates how plastic pollution on the seabed is currently extended worldwide. Topography, currents and their proximity to the source, such as large cities, will determine the preferential deposition sites of marine debris and plastics (Galgani et al. 1996, Galgani et al. 2000, Moore and Allen 2000). However, data on the distribution and abundance of plastic accumulation on the seabed are still scarce (Galgani et al. 2010) and even less is known regarding the long-term dynamics of plastic in the oceans.

In the Mediterranean Sea, plastic pollution has been the object of several scientific studies that aimed to evaluate its impact on the surface (Aliani and Molcard 2003) and on the seabed (Galgani et al. 2000). However, due to a lack of systematic evaluation and different methodological approaches, a comparison among areas is difficult ; in this context, the MSFD (MARINE STRATEGY FRAMEWORK DIRECTIVE) recommended systematically studying the amount, distribution and composition of litter, including plastics, on the sea floor (Galgani et al. 2010).

In the present paper we analyze the local and regional variability in the density and typology of marine benthic macrodebris over four areas located on Mediterranean continental shelves associated with trawling grounds. Therefore, the study will offer novel data on litter distribution over the Mediterranean seabed already impacted by different intensities of trawling effort. Fishing activities can also be a source of litter into the oceans (e.g. remains of fishing nets, boys, and vessel-associated garbage), and paradoxically the accumulation of marine debris might have negative effects on fishing activities (Nash 1992). In addition, in order to increase our knowledge on the long-term dynamics of the marine plastic debris accumulated on the seabed and its potential negative impact on the soft-bottom communities, the degree of plastic biocolonization was analysed.

Overall, this study aims to highlight the need for an integrated assessment of the ecosystem effects of these sources of impacts.

\section{MATERIALS AND METHODS}

\section{Study area}

The study focused on four distant areas associated with trawling grounds in the northern Mediterranean: one in Italy, the Central Tyrrhenian coast; one in Greece, the eastern Ionian coast; and two in Spain, the Murcian and Catalan coasts (Fig. 1). Information on commercial trawling activity was obtained from data gathered by the fishermen's' association. Within each area we selected three study sites subjected to different levels of fishing effort (high, medium and low fishing activity) and located between 40 and $80 \mathrm{~m}$ depth. In parallel, side scan sonar images recorded at the study sites showed the same three levels of fishing effort by analyzing the trawl marks (see more details in Demestre et al. 2010, de Juan and Demestre, 2012). The study sites all had mud and sandy mud habitats, with the exception of the Murcian sites, which were had heterogeneous substrates with gravely sand and maërl (Soto 1990).

\section{Data collection and analysis}

The experimental cruise was conducted from 21 May to 24 June 2009 in the aforementioned four Mediterranean areas. Sampling was simultaneously conducted for benthic debris and epibenthic fauna with an experimental surface dredge similar to a $2-\mathrm{m}$ beam trawl, with a $2 \mathrm{~m} \times 40 \mathrm{~cm}$ iron-framed aperture and a 10-mm cod-end.

The same sampling protocol was followed at each site, and a total of six replicate samples were randomly collected at each study site (1.5 ha sampled) within the four areas, following the sampling strategy used by epibenthic studies (de Juan et al. 2011). Each replicate consisted of a 15 -minute tow at $3 \mathrm{kn}$; to ensure continuous contact of the gear with the seabed, a scanmar sensor was placed on the iron frame of the dredge.

The marine debris collected with the surface dredge were classified on board into six general types: 1) plastic debris, 2) sanitary waste, 3) debris related to fishing activities, 4) glass, 5) metal, and 6) cloth. Objects classified in type 1 , plastic debris, were divided into plastic categories (bags, bottles, glasses, dishes, food packaging, tobacco products, toys, and non-identifiable pieces) and measured. 

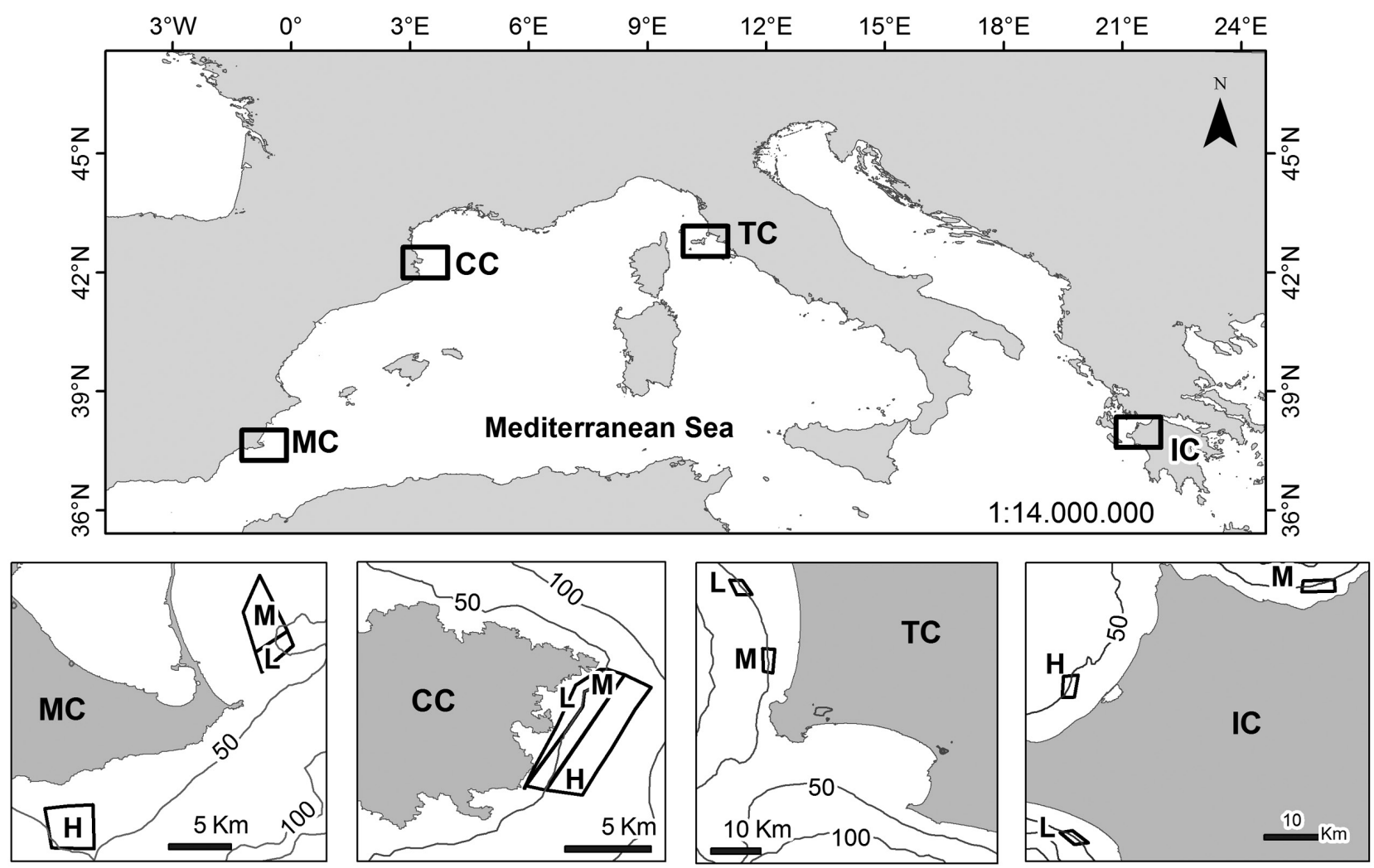

FIG. 1. - Study locations in the Mediterranean Sea. MC, Murcian coast (Spain); CC, Catalan coast (Spain); TC, Tyrrhenian coast (Italy); IC, Ionian coast (Greece). Detailed maps include the 3 sites surveyed in each area, with high (H), medium (M) and low (L) fishing activity.

Based on the results, the objects identified were grouped into the following categories for statistical analysis: soft plastic (plastic bags and bag pieces), cellophane (cigarette packaging, food packaging and nonidentifiable pieces), hard plastic (bottles and pieces, cups and plates, food packaging and others), semi-hard plastic, sanitary waste (sanitary towels and rarely adhesive bandages), remains of fishing gears (such as nets and lines) and latex-rubber or silicone. In addition, due to the low density found at all sites, glass, metal, cloth and wood were regrouped in the same typology (other debris). The significance of differences of these groups of debris between sites was assessed using the KruskalWallis rank test.

Additionally, two important aspects of plastic debris were analyzed: size and colonization by organisms. All benthic plastics collected were macroplastics (minimum length $>2 \mathrm{~cm}$ ) (Hidalgo-Ruz 2012). Plastics were grouped by size into 5 ranges $(\mathrm{cm})$ based on their maximum length:

\section{$2<x \leq 5 ; 5<x<10 ; 10 \leq x<20 ; 20 \leq x<50 ; x>50$.}

The colonization was assessed based on the organisms attached to the plastic and it ranged from primary colonization with biofilm to complete colonization. Five levels of colonization were considered. Attached organisms were identified to the lowest possible taxonomic level.
A two way PERMANOVA test (Anderson et al. 2008) based on the Bray-Curtis resemblance matrix after the debris density data, was used to test the significant effects of the terms Location (site) and Intensity (level of fishing intensity), which were considered as fixed crossed factors, on debris distribution. A multidimensional scaling ordination was performed with debris abundance from the Tyrrhenian coast, Ionian coast, Murcian coast and Catalan coast to visualize geographical patterns.

The SIMPER (similarity percentages) procedure was used to identify the most important items for typifying the groups: the Tyrrhenian coast, the Ionian coast, the Murcian coast and the Catalan coast. The cut-off for a low contribution was set at $90 \%$.

All the multivariate analyses were performed with the PRIMER 6+PERMANOVA software package from Plymouth Marine Laboratory, UK.

\section{RESULTS}

\section{Debris characterization}

A total of 555 pieces of debris were collected. Plastic bags and bag pieces were the most abundant items (37\% of the total), followed by cellophane type (28\%). Hard plastics accounted for $11 \%$ of the total debris, fishing-related debris $8 \%$, hygiene-related items only $2 \%$, and finally glass, metal, cloth and anthropogenic 
TABle 1. - Percentage of debris classified by type.

\begin{tabular}{|c|c|c|c|c|}
\hline Debris type & Percentage & & Type & Percentage \\
\hline $\begin{array}{l}\text { Plastic bags } \\
\text { Cellophane } \\
\text { Hard plastic } \\
\text { Fishing debris } \\
\text { Glass } \\
\text { Metal } \\
\text { Hygiene items } \\
\text { Cloth } \\
\text { Anthropogenic wood } \\
\text { Others }\end{array}$ & $\begin{array}{l}37 \\
28 \\
11 \\
8 \\
3 \\
1 \\
3 \\
3 \\
1 \\
5\end{array}$ & $\begin{array}{l}\text { Cellophane } \\
\text { Hard plastic } \\
\text { Fishing debris }\end{array}$ & $\begin{array}{l}\text { Food packaging } \\
\text { Tobacco packaging } \\
\text { Unidentified } \\
\text { Food packaging } \\
\text { Broken plates } \\
\text { Water bottles } \\
\text { Cups } \\
\text { Unidentified } \\
\text { Other bottles } \\
\text { Building material } \\
\text { Fishing lines } \\
\text { Rope } \\
\text { Net remains } \\
\text { Others }\end{array}$ & $\begin{array}{c}22 \\
12 \\
66 \\
13 \\
27 \\
22 \\
2 \\
15 \\
3 \\
5 \\
34 \\
51 \\
4 \\
11\end{array}$ \\
\hline
\end{tabular}

wood accounted for $3 \%, 3 \%, 1 \%$ and $1 \%$ of the total debris, respectively (Table 1 ).

\section{Size and colonization of benthic plastics}

Table 2 shows the percentage of main categories of plastic debris classified by size ranges and areas. In the four study areas the smaller pieces of plastic debris, $>2 \mathrm{~cm}$ and $<10 \mathrm{~cm}$, were the most abundant items $(57 \%)$. The abundance percentage of the other categories diminished with the size of the pieces.

A total of 462 plastic items were examined to assess their colonization. The identification and abundance of the organisms attached to the debris were used to determine the five levels of colonization:

- No organisms (0).

- Incrustation of nano- and micro-planktonic organisms (1).

- The first step of colonization with biofilm structures. Conspicuous green, green-brown or red patches are visible to the naked eye; SEM analysis showed microalgae, fungi and bacteria (Fortuño et al. 2010); few incrustations of macroalgae, Polychaeta or Bivalvia (consistently Anomia) (2).

- Incrustations of Polychaeta, Anomia, Bryozoa, and Cnidaria (3).

TABLE 2. - Percentage of plastic debris classified by size ranges at each location.

\begin{tabular}{lccccc}
\hline & $2<\mathrm{x} \leq 5$ & $5<\mathrm{x}<10$ & $10 \leq \mathrm{x}<20$ & $20 \leq \mathrm{x}<50$ & $>50$ \\
\hline Cellophane & 27 & 36 & 30 & 6 & 2 \\
Catalan coast & 31 & 44 & 19 & 0 & 6 \\
Ionian coast & 26 & 13 & 42 & 19 & 0 \\
Tyrrhenian coast & 26 & 41 & 27 & 3 & 2 \\
Murcian coast & 25 & 38 & 38 & 0 & 0 \\
Hard plastic & 40 & 27 & 27 & 6 & 0 \\
Catalan coast & 46 & 43 & 11 & 0 & 0 \\
Ionian coast & 24 & 18 & 47 & 12 & 0 \\
Tyrrhenian coast & 40 & 7 & 40 & 13 & 0 \\
Murcian coast & 67 & 33 & 0 & 0 & 0 \\
Soft plastic & 25 & 24 & 34 & 15 & 3 \\
Catalan coast & 25 & 29 & 29 & 17 & 0 \\
Ionian coast & 24 & 24 & 29 & 20 & 2 \\
Tyrrhenian coast & 26 & 24 & 38 & 8 & 5 \\
Murcian coast & 18 & 14 & 36 & 32 & 0 \\
Total & 28 & 29 & 32 & 10 & 2 \\
\hline
\end{tabular}

- The same organisms as in 3 with the addition of Ascidiacea, Porifera and ramified Cnidaria (4).

- Plastic surface almost completely covered by organisms (5).

Table 3 shows the degree of colonization of hard and soft plastics (bags and cellophane) in the four study areas. Level 1 accounted for $42 \%$ of the total plastics; levels 2 and 3 accounted for 46\%; plastics with high levels of colonization, levels 4 and 5, accounted for low percentages. The highest percentages for levels 4 and 5 were obtained for hard plastics in Greece, Italy and Murcia, and soft plastics in Murcia. Only $8 \%$ of the plastics showed no sign of colonization to the naked eye.

\section{Spatial variability}

High variability between samples was detected. Overall debris density ranged from 0 to 405 pieces per hectare ( $\mathrm{pd} / \mathrm{ha}$ ) (the latter detected in the medium fishing intensity area on the Catalan coast). No debris was found in five of the samples (four on the Murcian coast and one on the Catalan coast).

Average abundance of marine debris collected at the different locations showed that soft plastics were the most important items, ranging from $27.38 \pm 19.8$ at the Tyrrhenian coast medium fishing intensity site to 0 $\mathrm{pd} / \mathrm{ha}$ at the Catalan coast low fishing intensity site. On

TABLE 3. - Degree of colonization, in percentages, of hard plastic and soft plastic (bags and cellophane types) at each location

\begin{tabular}{lcccccc}
\hline Degree of colonization & 0 & 1 & 2 & 3 & 4 & 5 \\
\hline Catalan coast & 15.2 & 50.6 & 11.4 & 21.5 & 1.3 & 0.0 \\
soft plastic & 17.6 & 51.0 & 13.7 & 17.6 & 0.0 & 0.0 \\
hard plastic & 10.7 & 50.0 & 7.1 & 28.6 & 3.6 & 0.0 \\
Ionian coast & 7.1 & 48.5 & 10.1 & 22.2 & 11.1 & 1.0 \\
soft plastic & 6.1 & 53.7 & 12.2 & 20.7 & 6.1 & 1.2 \\
hard plastic & 11.8 & 23.5 & 0.0 & 29.4 & 35.3 & 0.0 \\
Tyrrenian coast & 6.9 & 39.9 & 17.7 & 22.6 & 8.1 & 4.8 \\
soft plastic & 6.4 & 41.2 & 18.0 & 22.7 & 6.9 & 4.7 \\
hard plastic & 13.3 & 20.0 & 13.3 & 20.0 & 26.7 & 6.7 \\
Murcian coast & 5.6 & 19.4 & 0.0 & 33.3 & 30.6 & 11.1 \\
soft plastic & 3.0 & 21.2 & 0.0 & 33.3 & 30.3 & 12.1 \\
hard plastic & 33.3 & 0.0 & 0.0 & 33.3 & 33.3 & 0.0 \\
Total general & 8.2 & 42.0 & 13.6 & 23.2 & 9.3 & 3.7 \\
\hline
\end{tabular}




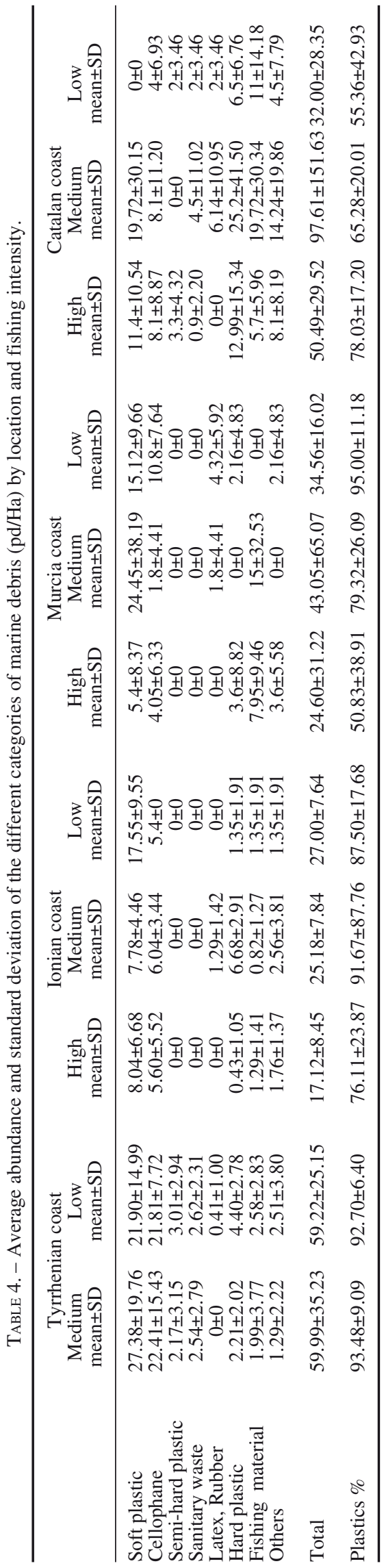

Fishing material

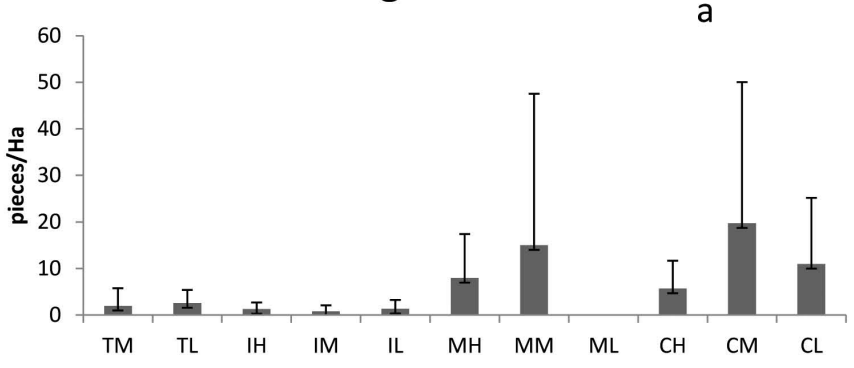

Soft plastic

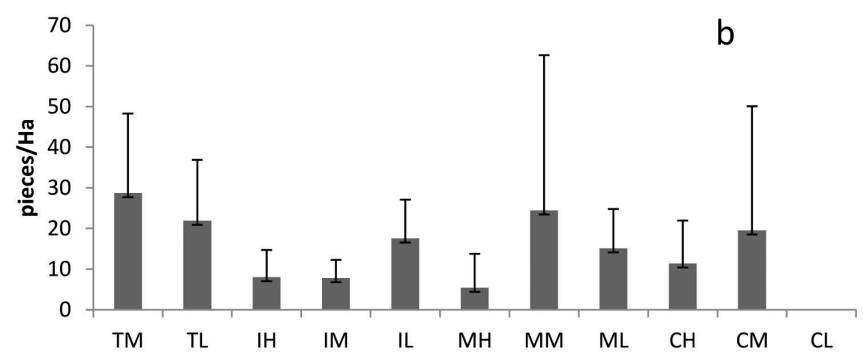

Hard plastic

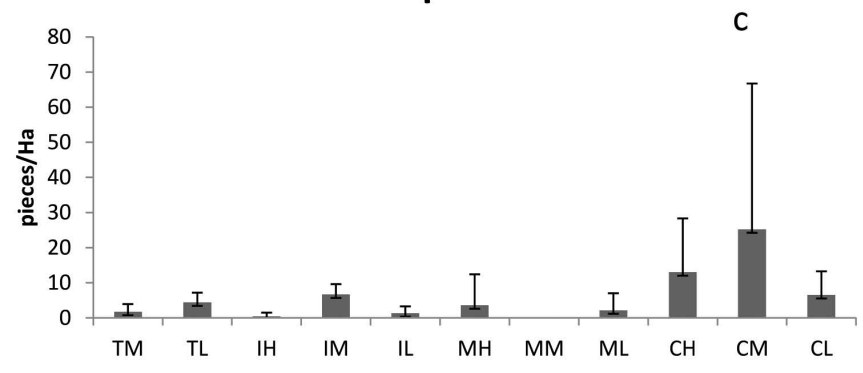

Total plastics

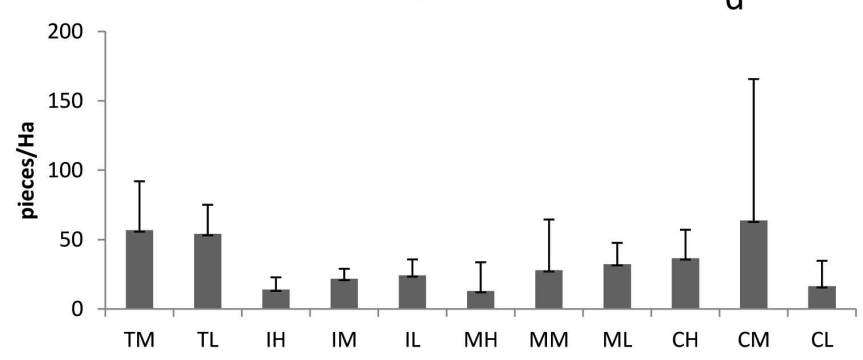

FIG. 2. - Quantities of debris (pd/ha) of: a) Fishing material; b) Soft plastic; c) Hard plastic; d) Total plastics (hard, soft and semi hard plastics) collected at the study locations under different fishing effort. TM, Tyrrhenian coast medium intensity; TL, Tyrrhenian coast low intensity; IH, Ionian coast high intensity; IM, Ionian coast medium intensity; IL, Ionian coast low intensity; MH, Murcian coast high intensity; MM, Murcian coast medium intensity; ML, Murcian coast low intensity; $\mathrm{CH}$, Catalan coast high intensity; $\mathrm{CM}$, Catalan coast medium intensity; $\mathrm{CH}$, Catalan coast low intensity

the Catalan coast the most important debris were hard plastics, whose abundance was highest at the medium fishing intensity site $25.2 \pm 41.5$ $\mathrm{pd} / \mathrm{ha}$ (Table 4).

The average density of other debris (glass, metal, cloth and wood) was very low in comparison with debris of plastic origin at all sites. The abundance of remains of fishing material in samples from the Murcian $(15 \pm 32.53 \mathrm{pd} / \mathrm{ha})$ and Catalan coast $(19.72 \pm 30.34 \mathrm{pd} / \mathrm{ha})$ was far higher 
TABLE 5. - Results of 2-factor PERMANOVA test for differences in debris composition. Significant differences are indicated: $* \mathrm{p}<0.01$.

\begin{tabular}{lccccc}
\hline Source & df & SS & MS & Pseudo-F & P(perm) \\
\hline Location & 3 & 12607 & 4202.2 & 3.5404 & $0.0011^{*}$ \\
Intensity & 2 & 1701 & 850.5 & 0.71656 & 0.6314 \\
Location $\times$ Intensity & 5 & 8099.2 & 1619.8 & 1.3647 & 0.1927 \\
Res & 42 & 49851 & 1186.9 & & \\
Total & 52 & 73706 & & & \\
\hline
\end{tabular}

than on the Ionian coast $(0.82 \pm 1.27 \mathrm{pd} / \mathrm{ha})$ (Fig. 2a).

Taking into account soft, hard and total plastics (Fig. 2b, c, d) there were significant differences for the overall comparison between locations (Kruskal-Wallis $\mathrm{p}<0.05$ ). The comparison between groups of debris indicated significant differences between locations for soft plastic $(\mathrm{p}=0.004)$, hard plastic $(\mathrm{p}=0.002)$ and total plastic $(\mathrm{p}=0.005)$.

None of the results of the Kruskal-Wallis test of differences between fishing intensities were significant ( soft plastic $\mathrm{p}=0.08$, hard plastic $\mathrm{p}=0.8$ and total plastic $\mathrm{p}=0.1$ ).

Non-significant differences between locations and fishing effort were observed regarding fishing debris and other debris. The standard deviation was high as their presence was sporadic.

In order to analyze the effects of fishing activity and geographic location on multivariate composition of debris density, a PERMANOVA analysis was conducted. The results revealed significant differences only for the term Location (Table 5). A more accurate analysis of the differences in debris density between sites within each area was done with MDS, but results showed no clear separation between samples from different locations regarding fishing intensity.

High variability between samples was detected regarding the percentage contribution of different types of debris by location. This variability was observed for

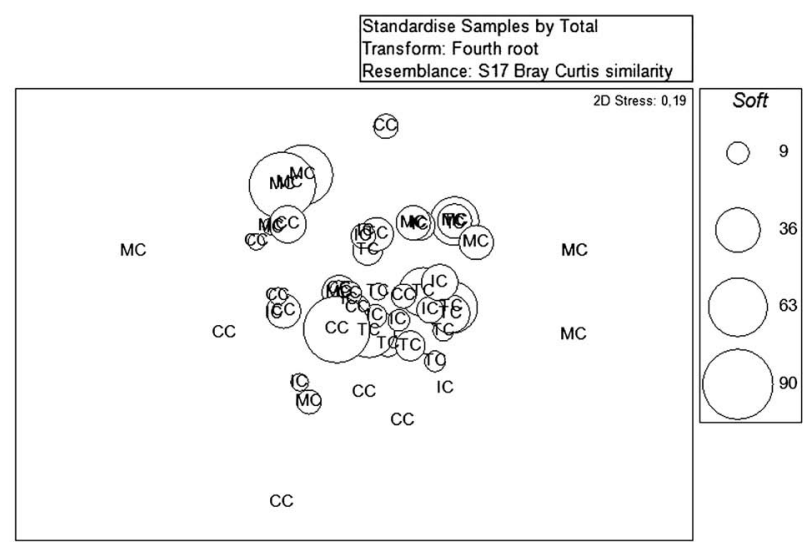

FIG. 3. - Multi-dimensional scaling ordination based on the debris density matrix. The size of the bubbles defines the average density of soft plastic in every sample. TM, Tyrrhenian coast medium intensity; TL, Tyrrhenian coast low intensity; IH, Ionian coast high intensity; IM, Ionian coast medium intensity; IL, Ionian coast low intensity; MH, Murcia coast high intensity; MM, Murcian coast medium intensity; ML, Murcian coast low intensity; $\mathrm{CH}$, Catalan coast high intensity; $\mathrm{CM}$, Catalan coast medium intensity; $\mathrm{CH}$, Catalan coast low intensity.

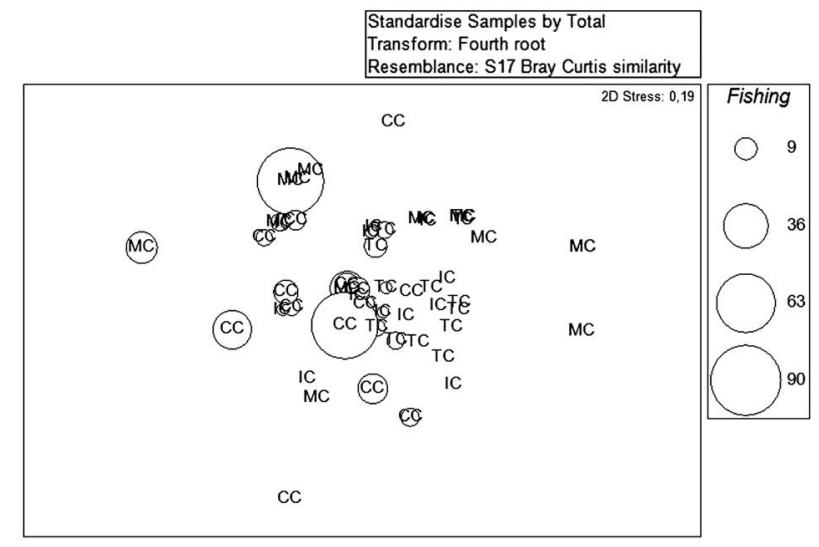

FIG. 4. - Multi-dimensional Scaling (MDS) ordination based on the debris density matrix. The size of the bubbles defines the average density of fishing debris in every sample. TM, Tyrrhenian coast medium intensity; TL, Tyrrhenian coast low intensity; IH, Ionian coast high intensity; IM, Ionian coast medium intensity; IL, Ionian coast low intensity; MH, Murcia coast high intensity; MM, Murcian coast medium intensity; ML, Murcian coast low intensity; $\mathrm{CH}$, Catalan coast high intensity; CM, Catalan coast medium intensity; $\mathrm{CH}$, Catalan coast low intensity.

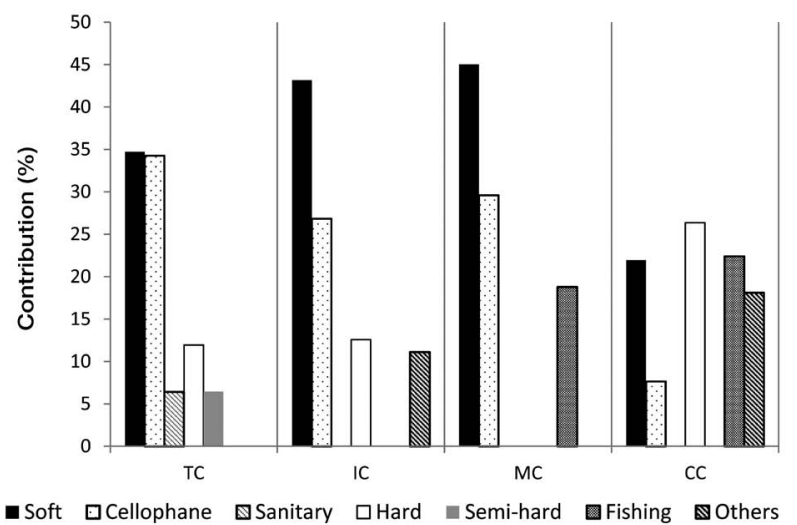

FIG. 5. - Percentage of the contribution of the most important debris' categories by SIMPER analysis. TC, Tyrrhenian coast (Italy); IC, Ionian coast (Greece); MC, Murcian coast (Spain); CC, Catalan coast (Spain).

soft plastics (Fig. 3), which had a high contribution to the total debris in samples from all locations, and for fishing gear debris (Fig. 4), which mainly appeared in samples from the Murcian and Catalan coasts.

According to the SIMPER analysis, five main debris categories contributed to debris abundance in samples from the Tyrrhenian coast, four in those from the Ionian coast, and three in those from the Murcian coast. Overall, the most important debris categories in these areas were soft plastic and cellophane. Five categories contributed to the Catalan coast samples, hard plastic being the most important debris category, followed by

TABLE 6. - Bray-Curtis dissimilarity percentage between locations.

\begin{tabular}{lccc}
\hline & Tyrrhenian coast & Ionian coast & Murcian coast \\
\hline Ionian coast & 38.57 & & \\
Murcian coast & 53.99 & 51.96 & \\
Catalan coast & 47.34 & 46.26 & 61.12 \\
\hline
\end{tabular}


remains of fishing material and soft plastic (Fig. 5). SIMPER dissimilarity between groups showed that Murcia coast group had more than $50 \%$ dissimilarity with the other three groups (Table 6).

\section{DISCUSSION}

\section{Spatial distribution and density of debris}

Several approaches have been adopted to evaluate the abundance of debris on the sea floor, and the review by Galgani et al. (2010) of the different methods used to date considers that the beam trawl survey is the best approach. However, these are partial results since they are only related to those areas where trawling operations can be carried out. We collected debris samples with an experimental surface dredge similar to a 2-m beam trawl that was towed over soft bottoms between 40 and $80 \mathrm{~m}$ depth in areas with different fishing intensities, and the results reflected the variable distribution of macrodebris, composition and degree of colonization by attached fauna. The variability in debris accumulation between areas was lower than between sites, indicating the importance of small-scale distribution of debris over the continental shelves. The accumulation of plastic debris over the ocean bottom is patchy for a variety of reasons, including local wind and current dynamics, coastline geography and the sources of entry into the system, such as urban areas, trading routes and large rivers. Once plastic reaches the marine environment, pulled directly or indirectly via other routes (rivers, wind, storms, natural disasters, etc.), it can travel considerable distances transported by the wind and currents until eventually it sinks and reaches the seabed. The sinking process depends on the specific density of the polymers, but the factors that determine this process are still poorly understood. Biofouling may be one of the determinants (Ye and Andrady 1991, Lobelle and Cuniliffe 2011) and Morét-Ferguson et al. (2010) evidenced the change in plastic specific density in contact with the marine environment and related to microorganism biofouling. Preferential deposition sites have been associated with areas of low circulation and high sediment accumulation (Galgani et al. 2010).

The Mediterranean Sea is one of the world's marine biodiversity hotspots and yet it is subjected to high anthropogenic pressure (Coll et al. 2010). Galgani et al. (2000) report data suggesting that the seafloor of the Mediterranean is one of the most polluted habitats in Europe. They estimated mean concentrations of 19.35 total $\mathrm{pd} / \mathrm{ha}$ in the NW Mediterranean but lower mean values were estimated for the Adriatic Sea, the Gulf of Lions and eastern Corsica. The average debris density recorded in the four areas included in this study was higher (60 pd/ha, $59.5 \mathrm{pd} / \mathrm{ha}, 34 \mathrm{pd} / \mathrm{ha}, 23 \mathrm{pd} / \mathrm{ha}$ for the Catalan, Tyrrhenian, Murcian and Ionian coasts respectively). Nevertheless, the overall concentration of macrodebris on the seafloor in our study areas (0-405pd/ha) was not higher than the concentration estimated in other studies also conducted in the Mediterranean. In Greek coastal areas 0-2513 pd/ha were detected (Katsanekis and Katsarou 2004) and in the Gulf of Lions Galgani et al. (2000) obtained ranges between 0 and $1010 \mathrm{pd} / \mathrm{ha}$. In the latter area, the presence of large amounts of debris was related to urban activity from Marseille and to a lesser extent from other large cities such as Nice. The relatively high density detected in the present study could be due to the high amount of plastic fragments of rather small size $(28 \%$ and $29 \%$ of $<5 \mathrm{~cm}$ and $<10 \mathrm{~cm}$, respectively). Currently, $\mathrm{pd} / \mathrm{ha}$ is considered the best measure to compare data regarding marine debris, as the weight of items is highly variable. However, the analysis of the plastic size showed that this is an important variable to analyze in conjunction with density ( $\mathrm{pd} / \mathrm{ha}$ ). Moreover, our results highlight that the high spatial variability found between replicates in the present study must be taken into account for future studies that should consider small-scale heterogeneity in debris distribution.

Fishing activities could be an important source of litter to the seabed, and in this context, we aimed to determine whether debris density was linked with fishing activities. Feder et al. (1978) published the first register of fishing areas in the Bering Sea having higher amounts of benthic debris than nearby non-fished areas. Hess et al. (1999) indicated that marine debris, particularly fishery-related debris, was commonly collected with benthic trawls in the Kodiac Island region. However, there is a relatively small population on Kodiac Island compared with the region where the European studies were conducted (Galgani 1995, 2000, our study) and in the Kodiac region the density of benthic debris was accordingly also lower. Though our study was conducted in trawl fishing grounds subjected to different effort intensities, no relationship between the density and composition of debris and fishing intensity was detected. Moreover, the fishing debris (e.g. remains of fishing nets) was generally scarce and did not show significant differences regarding either the location or the sites with variable fishing activities. Higher density of fishing debris was observed in areas adjacent to marined protected areas: on the Catalan coast and the Murcian coast (Fig. 1), but due to the high standard deviation no statistical differences were detected. This higher density of fishing gear remains could be related to artisanal fishing activities occurring in these coastal marine protected areas, e.g. gillnets or long-lines (fishing gears that are deployed over the seabed, frequently rocky bottoms, and that can easily get entangled in the bottom and therefore abandoned there) (Gómez et al 2006, Badalamenti et al. 2000, Sarda et al. 2012).

Typological analysis of our debris samples showed that plastics accounted for between $50.8 \%$ and $95 \%$ of the total debris abundance, depending on the zone (Table 2), and this is fairly consistent with previous findings. Galgani et al. (1995) found that plastic debris accounted for $77 \%$ of total debris on the sea bottom around Corsica. Stefatos et al. (1999), in Echinadhes 
Gulf and Patras Gulf (western Greece), described plastics as the most important debris component (79-83\%). According to Kanehiro et al. (1996), plastics reached $80-85 \%$ of the seabed debris in Tokyo Bay.

\section{Consequences for benthic marine ecosystem}

Our understanding of plastic degradation processes and direct and indirect effects on the marine environment is still slight. Our study shows a high percentage of plastics in the first phase of the succession process under colonization by microorganisms (microalgae, fungi and bacteria). This could be an indication of recent sinking of the plastic debris. It is worth mentioning that we collected some benthic plastics with encrusted Cirripeda (Lepas sp), typical colonizers of surface floating plastics (Aliani and Molcard 2003). As suggested by Goldberg (1997), once in the ocean plastics suffer a process of colonization that, in combination with the effect of currents, causes them to sink to the ocean seabed. Once on the seabed, as our data evidenced, the process of colonization continues and macro-organisms, such as Polychaeta, Bryozoa and Cnidaria, become encrusted in this new substrate. This colonization process obviously maintains plastics on the seabed and thus potentially modifies the ecosystem structure and functioning, e.g. by creating anoxic areas or providing hard substrates for the attachment of organisms (Derraik 2002).

Epifaunal species are good indicators of the benthic ecosystem degradation due to their limited mobility and tight link with their habitat. Regarding fishing impacts, de Juan and Demestre (2012), showed that a set of biological traits of the epifaunal species, which had been previously related to trawling disturbance responses, could be significantly linked with trawling disturbance intensity. For example, increased abundance of sessile filter feeders, such as sponges and gorgonians, characterized the less disturbed sites. However, the areas associated with trawling grounds generally harbour chronically disturbed communities dominated by small and mobile invertebrates that can sustain continuous disturbance (de Juan et al. 2007, de Juan et al. 2011). In the present study, relationships between the epibenthic community structure and the functional composition and density of plastic debris were tested but no significant interactions were observed (unpublished data). The four areas we sampled through the Mediterranean are within fishing grounds and the chronic disturbance of commercial trawling activities probably has such profound effects on benthic communities (de Juan et al. 2007) that no interaction between the local epifaunal communities and marine debris could be detected. Currents can transport plastics from one location to another and in this process sessile organisms would be damaged, whereas active motile organisms can escape. In an experimental study, Katsanevakis et al. (2007) demonstrated changes in marine benthic communities related to the accumulation of debris on the seabed. On the other hand, we analyzed the organisms colonizing the plastic debris from our study areas and observed that plastic debris were highly colonized by organisms typical of hard bottoms, e.g. Briozoa, sabellid Polychaeta, sessile Bivalvia, Ascidia and encrusting Porifera, evidencing alteration of the community composition. Most of these species are primarily inhabitants of rocky or gravelly bottoms, with hard structures for the attachment of organisms, and should be absent from purely muddy bottoms. These species colonizing plastics were not included in the epifaunal community data set, and this could also partly explain the lack of relationships between the epifaunal community and density of plastics.

As a concluding remark, we highlight that the colonization of plastic debris by organisms might have further consequences for the functioning of the ecosystem. For example, it may modify the habitat at a small spatial scale and facilitate the introduction of species, leading to new negative/positive species interactions that could operate at larger scales. Additional studies of the species interactions arising from plastic introduction in the environment and modification of the ecosystem functioning should be undertaken to investigate potential secondary effects of the accumulation of plastic debris on the seabed. These potential effects, and their interaction with other sources of disturbance, such as fishing with trawled nets, should be further assessed in a context of increasing human activities in coastal zones that imply multiple sources of stress to ecosystems, including the accumulation of plastic debris on the ocean floor.

\section{ACKNOWLEDGEMENTS}

Data used in this work were collected in the framework of the research project COMSOM (CTM200804617/MAR) funded by the Spanish "Ministerio de Ciencia e Innovación". We thank our colleagues A. Ligas, M. Sartini, Ch. Mytilineou, K. Papadopoulou, P. Sartor and P. Martín for their collaboration. The authors wish to thank to the crew of the V/R Garcia del Cid and the participants of the oceanographic cruise.

\section{REFERENCES}

Aliani S., Molcard A. 2003. Hitch-hiking on floating marine debris: macrobenthic species in the Western Mediterranean Sea. Hydrobiologia 503: 59-67.

Anderson M.J., Gorley R.N., Clarke K.R. 2008. PERMANOVA+ for PRIMER: Guide to Software and Statistical Methods. The University of Auckland Press, 214 pp.

Badalamenti F., Ramos A.A., Voultsiadou E., Sánchez Lizaso J.L., D’anna G., Pipitone C., Mas J., Ruiz Fernandez J.A., Whitmarsh D., Riggio S. 2000. Cultural and socio-economic impacts of Mediterranean marine protected areas. Environ. Conserv. 27: $110-125$.

Barnes D.K.A. 2002. Biodiversity - Invasions by marine life on plastic debris. Nature 416: 808-809

Barnes D.K.A., Galgani F., Thompson R.C., Barlaz M. 2009. Accumulation and fragmentation of plastic debris in global environments. Phil. Trans. R. Soc. B 364: 1985-1998.

Coll M., Piroddi C., Steenbeek J., Kaschner K., Ben Rais Lasram 
F., Aguzzi J., Ballesteros E., Bianchi C.N., Corbera J., Dailianis T., Danovaro R., Estrada M., Froglia C., Galil B.S., Gasol J.M., Gertwagen R., Gil J., Guilhaumon F., Kesner-Reyes K., Kitsos M.S., Koukouras A., Lampadariou N., Laxamana E., López-Fé de la Cuadra C.M., Lotze H.K., Martin D., Mouillot D., Oro D., Raicevich S., Rius-Barile J., Saiz-Salinas J.I., San Vicente C., Somot S., Templado J.,Turon J.X., Vafidis D., Villanueva R., Eleni Voultsiadou E. 2010. The biodiversity of the Mediterranean Sea: estimates, patterns, and threats. PLoS ONE, 5(8): e11842.

de Juan S., Demestre M. 2012. A Trawl Disturbance Indicator to quantify large scale fishing impact on benthic ecosystems. Ecol. Indic. 18: 183-190.

de Juan S., Thrush S.F., Demestre M. 2007. Functional changes as indicators of trawling disturbance on a benthic community located in a fishing ground (NW Mediterranean Sea). Mar. Ecol. Prog. Ser. 334: 117-129.

de Juan S., Demestre M., Sanchez P. 2011. Exploring the degree of trawling disturbance by the analysis of benthic communities ranging from a heavily exploited fishing ground to an undisturbed area. Sci. Mar. 75: 507-516.

Demestre M., Martin J., Mytilineou C., Sartor P., Mas J., Sanchez P., de Juan S., Maso M., Martin P., Lo Iacono C. 2010. Evaluation of the level of trawling perturbation on soft bottoms using acoustic remote sensing as a promising approach for fishing effort estimation. Rapp. Comm. int. Mer Médit. 39: 489.

Derraik J.G.B. 2002. The pollution of the marine environment by plastic debris: a review. Mar. Pollut. Bull. 44: 842-852.

Feder H.M., Jewett S.C., Hilsinger J.R. 1978. Man-made debris on the Bering Sea floor. Mar. Pollut. Bull. 9: 52-53.

Fortuño J.M., Masó M., Sáez R., de Juan S., Demestre M. 2010. SEM microphotographs of biofouling organisms on floating and benthic plastic debris. Rapp. Comm. int. Mer Médit. 39: 358.

Galgani F., Jaunet S., Campillo A., Guenegen X., Hi E. 1995. Distribution and abundance of debris on the continental shelf of the North-Western Mediterranean sea. Mar. Pollut. Bull. 30: 713-717.

Galgani F., Fleet D., Van Franeker, J. Katsanevakis S., MaesT. Oosterbaan L., Poitou I., Hanke G., Thompson R., Amato E., Janssen C. 2010. Marine Strategy Framework Directive. Task group 10 report Marine Litter; European Commission Joint Research Center, 48 pp.

Galgani F., Leaute Moguede J.P., Souplet A., Verin Y., Carpentier A., Goraguer H., Latrouite D., Andral B., Cadiou Y., Mahe J.C., Poulard J.C., Nerisson P. 2000. Litter on the sea floor along European coast. Mar. Pollut. Bull. 40: 516-527.

Galgani F., Souplet A., Cadiou Y. 1996. Accumulation of debris on the deep sea floor off the French Mediterranean coast. Mar. Ecol. Prog. Ser. 142: 225-234.
Goldberg E.D. 1997. Plasticizing the seafloor: an overview. Environ. Technol. 18: 195-202.

Gómez, S., Lloret J., Demestre M., Riera V. 2006. The decline of the artisanal fisheries in Mediterranean coastal areas: The case of Cap de Creus (Cape Creus). Coast. Manage. 34: 217-232.

Gregory M.R. 2009. Environmental implications of plastic debris in marine settings-entanglement, ingestion, smothering, hangerson, hitch-hiking and alien invasions. Phil. Trans. R. Soc. B 364: 2013-2025.

Hess N.A., Ribic C.A., Vining I. 1999. Benthic marine debris, with an emphasis on fishery-related items, surrounding Kodiak Island, Alaska, 1994-1996. Mar. Pollut. Bull. 38: 885-890.

Kanehiro H., Tokai T., Matsuda K. 1996. The distribution of litters on fishing grounds of Tokyo Bay. Fish. Eng. 32: 211-217.

Katsanevakis S., Verriopoulos G., Nicolaidou A., Thessalou-Legaki M. 2007. Effect of marine litter on the benthic megafauna of coastal soft bottoms: A manipulative field experiment. Mar. Pollut. Bull. 54: 771-778.

Lobelle D., Cunliffe M. 2011. Early microbial biofilm formation on marine plastic debris. Mar. Pollut. Bull. 62: 197-200.

Masó M., Garcés E., Pagés F., Camp J. 2003. Drifting plastic debris as a potential vector for dispersing harmful algal bloom (HAB) species. Sci. Mar. 67: 107-111.

Morét-Ferguson S., Lavender Law K., Proskurowski G., Murphy E.K., Peacock E.E., Reddy Ch.M. 2010. The size, mass, and composition of plastic debris in the western North Atlantic Ocean. Mar. Pollut. Bull. 60: 1873-1878.

Moore S.L., Allen M.J. 2000. Distribution of anthropogenic and natural debris on the mainland shelf of the Southern California Bight. Mar. Pollut. Bull. 40: 83-88.

Nash A.D. 1992. Impacts of marine debris on subsistence fishermen - an exploratory-study. Mar. Pollut. Bull. 24(3): 150-156.

Sarda R., Rossi S, Martí X., Gili J.M. 2012. Marine benthic cartography of the Cap de Creus (NE Catalan Coast, Mediterranean Sea). Sci. Mar. 76: 159-171.

Soto J. 1990. Vegetación algal sobre sustrato móvil de la zona circalitoral del Sureste de la Península Ibérica: una aproximación. Folia Bot. Misc. 7: 43-49.

Stefatos A., Charalampakis M., Papatheodorou G., Ferentinos G. 1999. Marine debris on the seafloor of the Mediterranean sea: Examples from two enclosed gulfs in Western Greece. Mar. Pollut. Bull. 36: 389-393.

Ye S., Andrady A.L. 1991. Fouling of floating plastic debris under Biscayne Bay exposure conditions. Mar. Poll. Bull. 22: 608-613.

Scient. ed.: R. Sardá.

Received July 26, 2012. Accepted March 26, 2013.

Published online May 10, 2013. 